研究

\title{
$\mathrm{Nd}-\mathrm{Fe}-\mathrm{B}$ 異方性スプレー造粒粉の磁界配向
}

\author{
槇田顕山1, 山下 治山1, 伊藤 崇的, 高橋 朝彦的 2 \\ 41 住友特殊金属侏研究開発部， $\mathrm{T}$ 618-8555 大阪府三島郡島本町江川 2-15-17. \\ 《2 大川原化工機侏技術開発部， $=224-0053$ 横浜市都筑区池辺町 3847.
}

\section{Magnetic Field Alignment of the Anisotropic Spray Dried Nd-Fe-B Powder}

\author{
Ken Makita ${ }^{\not 1}$, Osamu Yamashita ${ }^{\text {1 }}$, Takashi Ito ${ }^{2}$ and Tomohiko Takahashi ${ }^{2}$ \\ ${ }^{4}{ }^{1}$ Research \&Development Department, Sumitomo Special Metals Co., Ltd., 2-15-17 Egawa Shimamoto-cho Mishima-gun, Osaka 618-8555.

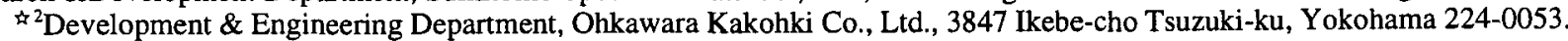

Received September 9, 1997

\section{SYNOPSIS}

A process to obtain the anisotropic spray dried Nd-Fe-B powder has been studied in order to improve the poor alignment of sintered magnets synthesized by the usual isotropic spray dried powder. A magnetic field of 0.12 $\mathrm{MA} / \mathrm{m}$ was applied transversely to the flow of droplet where it dried up to be granulated powder which has a good flowability. The measurement of the initial magnetization curve and the X-ray diffraction patterns revealed that the easy axis of powders aligns to the direction of the external field more easily compared with the isotropic powder spray dried in the same condition without a magnetic field. It suggests that our spray dried powder is anisoptropic; Nd-Fe-B fine powder included in each granular is uniaxially aligned. The alignment of the anisotropic spray dried powder in a low field is dominated by the rotation of granulated powder. When the strength of the magnetic field at compacting is $0.23 \mathrm{MA} / \mathrm{m},(\mathrm{BH})_{\max }$ of the sintered magnet obtained from the anisotropic spray dried powder exceeds by $19.2 \%$ than the value for the isotropic one.

\section{KEY WORDS}

$\mathrm{Nd}-\mathrm{Fe}-\mathrm{B}$ magnet, spray drying, anisotropic spray dried powder, magnetic field alignment

\section{1 緒 言}

Nd-Fe-B 焼結磁石" は実用磁石材料の中で最も高性能な磁石 として知られ，さまざまな用途に使われている。この磁石の製 法は，母合金を粉砕して得た原料粉末を磁界中で成形した後， 焼結するいわゆる粉末冶金法によっている.成形に用いる原料 粉末の粒径は $3 \mu \mathrm{m}$ 程度である。

近年, 磁石を用いた機器の小型化への要求が高まり, 寸法の 小さな高性能磁石を用いて磁気回路の小型化がはかられてい る.小型の磁石を製造する場合に最も問題となるのは，原料粉 末の流動性である，すなわち，製品形状に合わせて成形に用い る金型の開口部のサイズを小さくすると,給粉量の変動が大き くなったり，極端な場合，原料粉末が金型内に全く入らなく なったりする。

最近, Nd-Fe-B 磁石の原料粉末の流動性を改善する手段とし て、スプレー造粒法による造粒が試みられている 2.37 .スプレー 造粒により，原料粉末は数十 $\mu \mathrm{m}$ の径を持つ二次粒子に造粒さ
れ，流動性は著しく改善される，また，この造粒粉は磁界中で 崩壊するため，磁界中成形も可能である.

ところが,磁界中成形した磁石の配向度を詳しく調べてみる と、スプレー造粒粉を用いた場合は原料粉末に比べて配向度が 低下しており，特に成形磁界が低いときはその差が著しい。こ のため,例えば一般に成形磁界の低いラジアル配向を行う磁石 の成形などにスプレー造粒粉を用いた場合,配向度が低くなり 十分な磁気特性が得られないという問題がある.

そこで, Nd-Fe-B原料粉末のスプレー造粒粉の磁界中での配 向度を高める目的で, 造粒操作を磁界中で行うことにより，一 次粒子の方位のそろった異方性のスプレー造粒粉の作製を試み たところ, 従来の等方性の造粒粉に比べて磁界中での配向性が 向上することがわかったので詳細を報告する.

\section{2 実験方法}

高周波溶解によって作製したNd-Fe-B 母合金を機械粉砕後， 
Table 1 Size distribution of spray dried powder.

\begin{tabular}{cccccccc}
\hline Spray dried powder & $<20$ & $20-45$ & $45-75$ & $75-150$ & $150-250$ & $250-590$ & $\mu \mathrm{m}$ \\
\hline Anisotropic & 0.4 & 12.2 & 33.0 & 43.3 & 7.2 & 3.8 & $\mathrm{wt} \%$ \\
Isotropic & 0.7 & 13.2 & 40.1 & 42.8 & 0.7 & 2.6 & $\mathrm{wt} \%$ \\
\hline
\end{tabular}

さらに窒素ガス中でジェットミル粉砕して，平均粒径 $2.9 \mu \mathrm{m}$ の原料粉末を得た，得られた原料粉末の組成は $\mathrm{Nd} 29.9 \mathrm{wt} \%$, Dy $1.0 \mathrm{wt} \%$, B $1.0 \mathrm{wt} \%, \mathrm{O} 0.55 \mathrm{wt} \%, \mathrm{C} 0.06 \mathrm{wt} \%$, 残部 $\mathrm{Fe}$ であっ た.これに,バインダーとしてポリビニルアルコール(PVA) の $10 \%$ 水溶液を原料粉末に対して $0.2 \mathrm{wt} \%$ 分，また，可塑剬と してグリセリンを $0.1 \mathrm{wt} \%$ 分だけ添加，混合し，さらに純水を 加えて濃度 65\%のスラリーを作製した. スラリー中での原料 粉末の酸化を防止するため，これらの操作はすべて 273〜278 Kの温度範囲で行った。

次に，Fig.1に示すような永久磁石による磁気回路を備えた スプレードライヤーに上述のスラリーを供給し, 窒素雲囲気 中, $373 \mathrm{~K}$ の乾燥温度で異方性のスプレー造粒を行った。回転 ディスクから飛び出した液滴が通過する磁気回路のギャップ 幅は 50mm，中心部の磁界強度は $0.12 \mathrm{MA} / \mathrm{m}$ ，磁界の向きは図 の上下方向である．回転ディスクから飛び出す液滴が磁気回 路のギャップの中心を通過するように磁気回路の高さを調整 することにより，磁気回路への液滴の付着量は問題のないレ ベルにまで抑制することができた，比較のために，磁気回路 を取り外して同一条件で等方性のスプレー造粒粉も作製した. いずれの試料も粗大粉を除去するために目の開きが $590 \mu \mathrm{m} の$ フルイを用いてオーバーカットを行った。

得られたスプレー造粒粉を金型に入れ，0〜0.88MA $/ \mathrm{m}$ の磁 界中で配向しながら $147 \mathrm{MPa}$ の圧力で成形した。ささらに, 成形

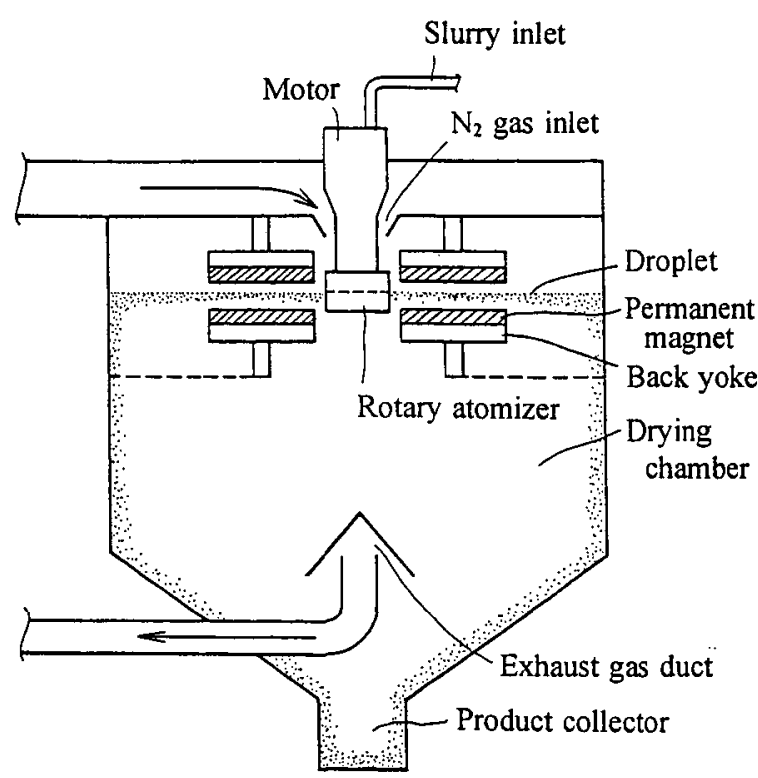

Fig.1 Schematic illustration of the spray dryer combined with a magnetic circuit.
体を水素流気中， $723 \mathrm{~K} て ゙ ~ 2 \mathrm{~h}$ 脱バインダー処理し，引き続き アルゴン流気中で1353K, 4hの焼結を行った後, 同じくアルゴ ン中で $773 \mathrm{~K}, 2 \mathrm{~h}$ の熱処理を行い，磁石試料を得た。磁石の磁 気特性は，試料をピーク強度 $3.2 \mathrm{MA} / \mathrm{m}$ のパルス磁界で着磁し た後，BHトレーサーで測定した. スプレー造粒粉の磁化曲線 は, $\phi 2.5 \times 7.5 \mathrm{~mm}$ のキャビティーサイズを持つサンプルホル ダーに試料を $30 \mathrm{mg}$ 封入し，試料振動型磁力計 (VSM) を用い て初期磁化曲線を測定した。磁界を加えたスプレー造粒粉の X線回折は，ガラス板に塗布したワセリンの上に造粒粉をふ りかけ，ガラス板に垂直に磁界を加えた後， $\theta-2 \theta$ スキャンニ ングによる回折パターンを測定した。

\section{3 実験結果および考察}

3.1 スプレー造粒粉の性状

本研究で得られた異方性スプレー造粒粉，および等方性ス プレー造粒粉は，いずれも原料粉末に比べて優れた流動性を 示した．両者の粒度分布をフルイを使って調べた結果を Table 1 に示す，造粒粉の二次粒子径の大きさは两者とも約 $80 \mathrm{wt} \%$ が 45-150 $\mu \mathrm{m}$ の範囲にあり，よく似た分布をしている. 平均の二 次粒子径 $\left(\mathrm{D}_{50}\right)$ の值は磁界中スプレー造粒粉が $103 \mu \mathrm{m}$, 磁界な しの通常のスプレー造粒粉が $89 \mu \mathrm{m}$ で，磁界中造粒粉の方がや や大きい.

これらの造粒粉をSEMで観察した結果を Fig.2の (a), (b)に それぞれ示す．造粒粉の形状に注目すると，等方性造粒粉 (b) は球状であるのに対して，異方性造粒粉(a)は細長い葉巻状を している，これは，造粒の過程において，磁界のない場合に は液滴が表面積が最小となる球状になった状態で乾燥するの に対して，磁界中では液滴に含まれる原料粉末が配向し，静 磁エネルギーが小さくなるように細長くなった状態で乾燥さ れるためと考えられる。

次に, スプレー造粒粉の初期磁化曲線をVSMで測定した結 果をFig.3に示す．比較のために，スプレー造粒前の原料粉末 の磁化曲線も合わせて示す．原料粉末に比べて等方性スプ レー造粒粉の磁化の立ち上がりは緩やかであるが，異方性 スプレー造粒粉では磁化の立ち上がりがやや急になり，磁界 強度1.2MA/mでの磁化も等方性のものに比べて高くなってい る.

Fig.3の初期磁化曲線は，外部磁界に対する個々の粉末粒子 の磁化の反転と粒子の配向に上る磁化の增加を示している. スプレー造粒前の原料粉末では粒子の回転を妨げる力は小さ いので，磁化反転とスムーズな磁界配向によって磁化は急激 に立ち上がる，等方性スプレー造粒粉では，一次粒子は互い 

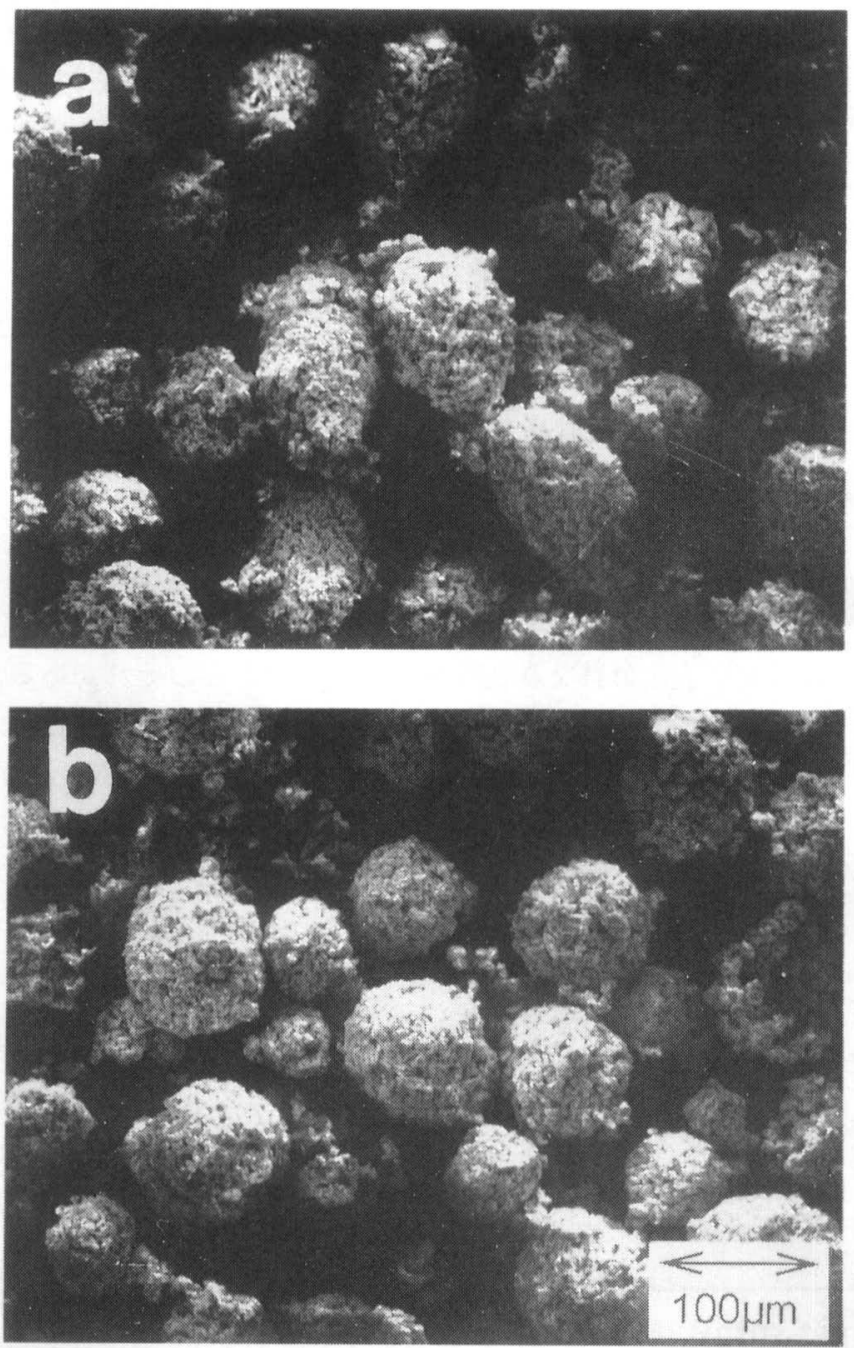

Fig.2 SEM images of Nd-Fe-B spray dried powder, (a); anisotropic and (b); isotropic. SEM samples are prepared without a magnetic field.

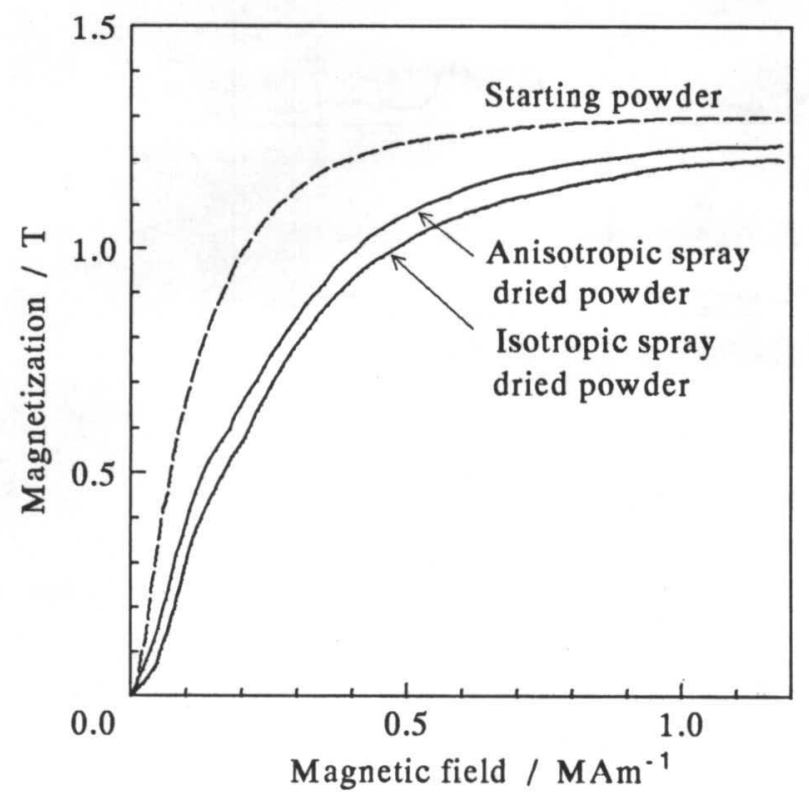

Fig.3 Initial magnetization curves of spray dried powders (solid lines), (a); anisotropic and (b); isotropic. A curve of starting powder (broken line) is also indicated for comparison.
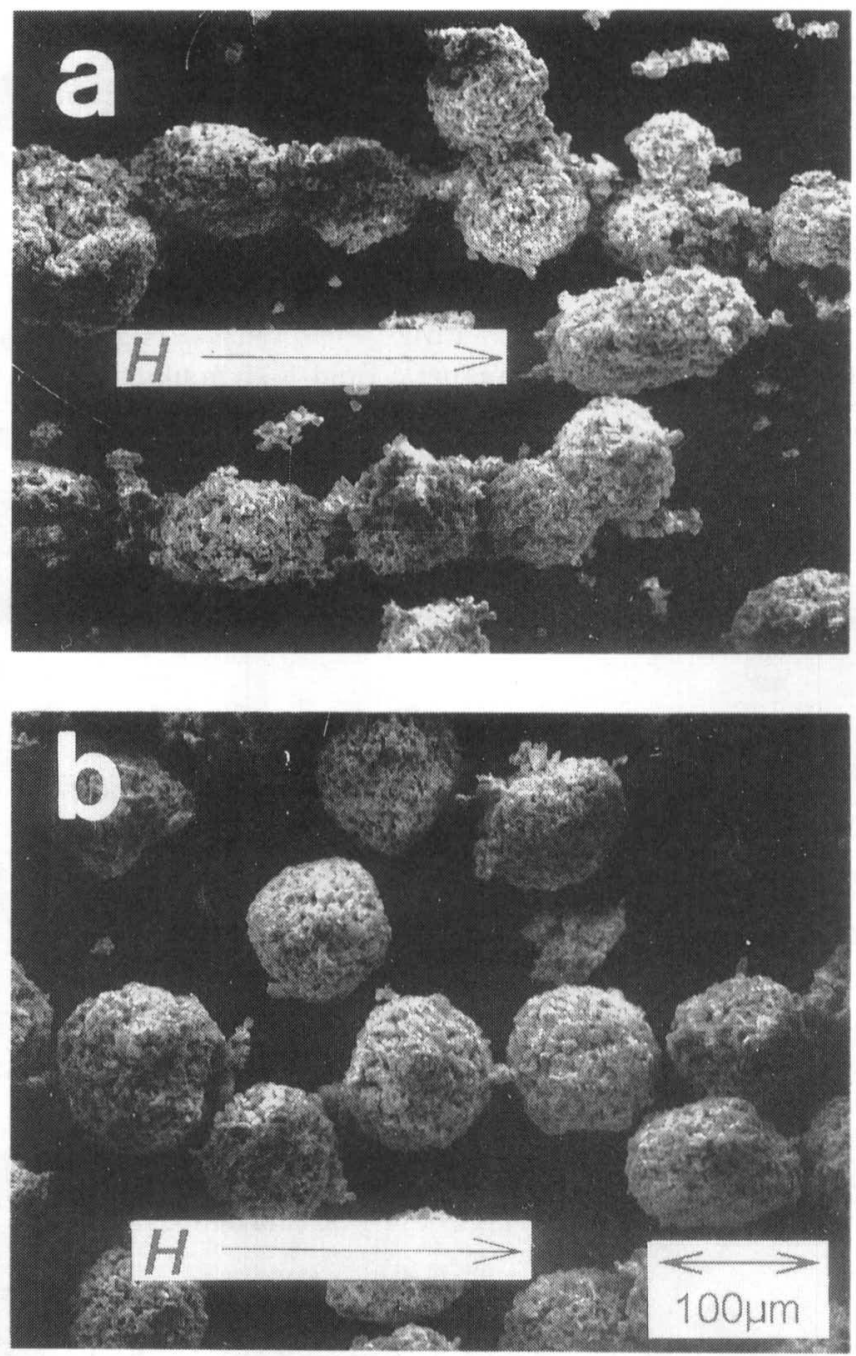

Fig.4 SEM images of Nd-Fe-B spray dried powder, (a); anisotropic and (b); isotropic, both of which are aligned with a magnetic field of $0.1 \mathrm{MA} / \mathrm{m}$. Arrows indicate the direction of the applied field.

にバインダーによってランダムな方向にゆるく固定されてお り, 強い外部磁界によってその結束が解かれて二次粒子が崩 壊することによって，はじめて磁界配向が可能になるため, 初期磁化曲線は緩慢になる，異方性スプレー造粒粉では，1 個の二次粒子中にふくまれる一次粒子の結晶方位が, 造粒中 に加えられた磁界によってある程度配向した状態で乾燥, 固 化しているため, Fig.2(a)に示した葉巻形状の長軸方向が磁化 容易軸となっており，低い磁化においても二次粒子全体の回 転により磁界配向が進むものと考えられる.

低い磁界中での造粒粉の配向の様子を実際に観察するため に, 異方性スプレー造粒粉と等方性スプレー造粒粉を $0.1 \mathrm{MA} / \mathrm{m}$ の静磁界中で導電性テープの上にふりかけて固定後, SEM観 察した結果を Fig.4に示す.このような低い磁界では造粒粉の 磁界による崩壊はほとんど起こっていない, また, 異方性ス プレー造粒粉では長軸方向が外部磁界の方向と一致するよう に回転した二次粒子同士が, 外部磁界の方向と平行に整列し ていることが確認できた(Fig.4(a)). 観察の結果から推定される 
Anisotropic spray dried powder
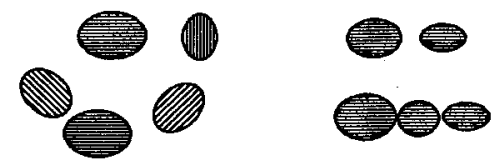

No fields

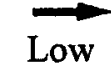
magnetic field

Isotropic spray dried powder

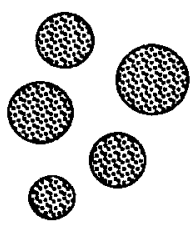

No fields

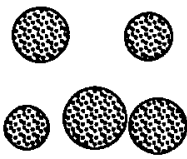

Low magnetic field
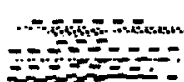

minesterse-

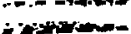

High magnetic field
比ベて (006) 面や (116) 面からの回折ピークの強度が低い配向 磁界に扑ても增加している。この結果はVSMによる磁気測 定の結果とよく一致して扔り，異方性スプレー造粒粉が優れ た配向性を持つことを結晶学的にも確認することができた．

ところで，このような比較検討を行う場合，造粒粉の磁界 配向性に抢上ほすす他の条件が同一であるかどうかを確認して おく必要がある。まず，バインダーの含有量と残留水分量に ついては，バインダー量は多いほど，残留水分は少ないほど 造粒粉の崩壤強度は高まり，磁界配向は困難になることが知 られている ${ }^{4}$. しかし，本研究に用いた 2 種類の造粒粉の炭素 分析值は $0.20 \mathrm{wt} \%$ ，残留水分量は $0.05 \mathrm{wt} \%$ といずれも同一で あった。

次に，バインダー含有量や残留水分量が同じでも，造粒粉 の二次粒子径が異なると磁界配向性が変わるおそれがある。 Fig.7はPVAを $0.4 \mathrm{wt} \%$ 含む等方性のスプレー造粒粉を分級し たときの初期磁化曲線を測定した例であるが，二次粒子径が 大きいほど磁界による造粒粉の崩壊が困難になることがわか る．ところが，本研究で用いた造粒粉は前述のように，異方 性スプレー造粒粉の平均の二次粒子径 $\left(\mathrm{D}_{50}\right)$ の方が等方性のも のに比べてむしろ大きな値をしているため，粒度の違いを考 慮しても磁界配向性に有意差があると考えてよい。

以上の考察から，これまで見てきた磁界中スプレー造粒粉 の優れた配向性は，個々の二次粒子にふくまれる一次粒子の 結晶方位がそろっていること，すなわち異方性の造粒粉に なっていることに起因していると結論づけることができる.

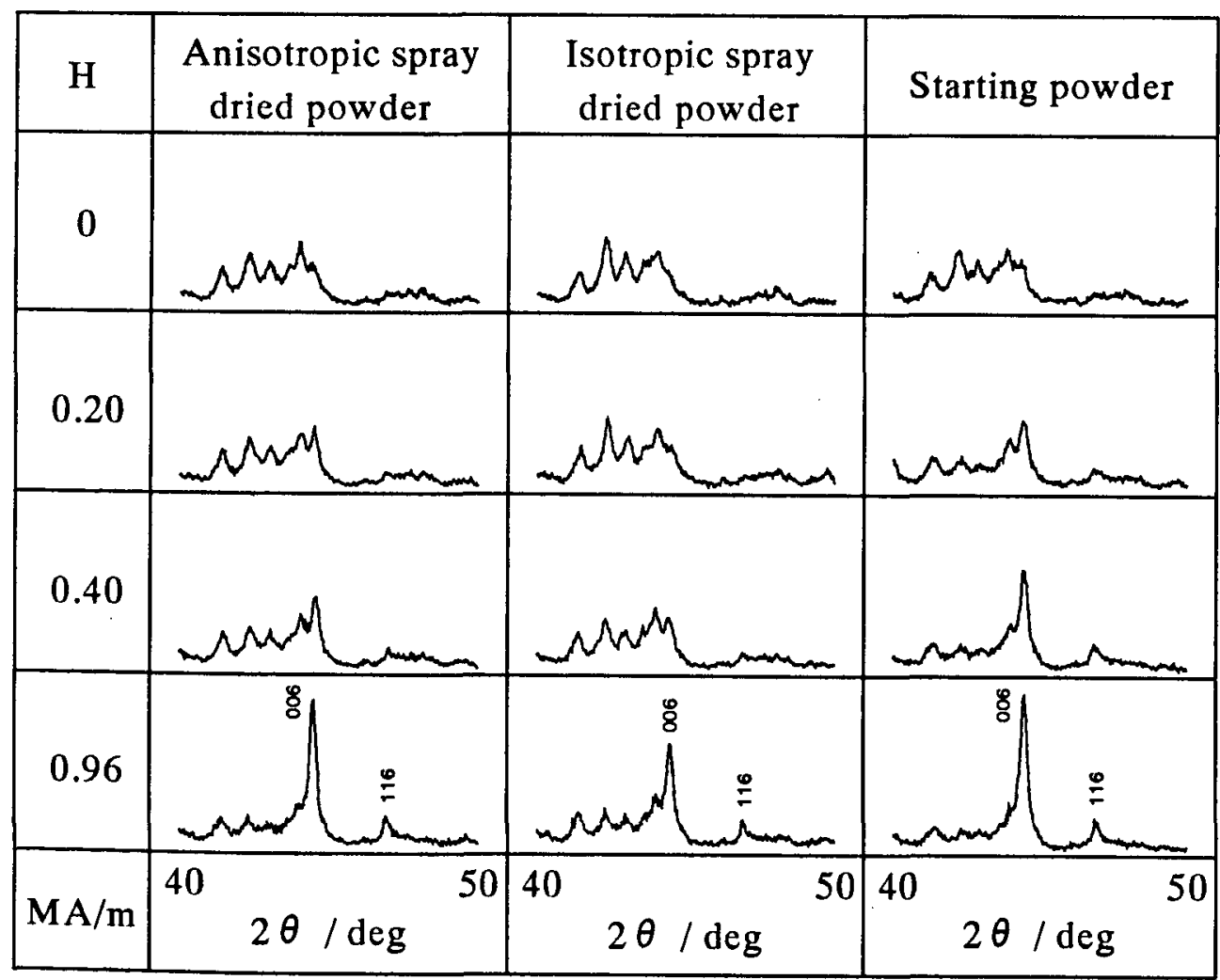

Fig.6 X-ray diffraction patterns of Nd-Fe-B powder aligned under magnetic fields applied parallel to the scattering vector. $\mathrm{H}$ is the strength of the applied field. 


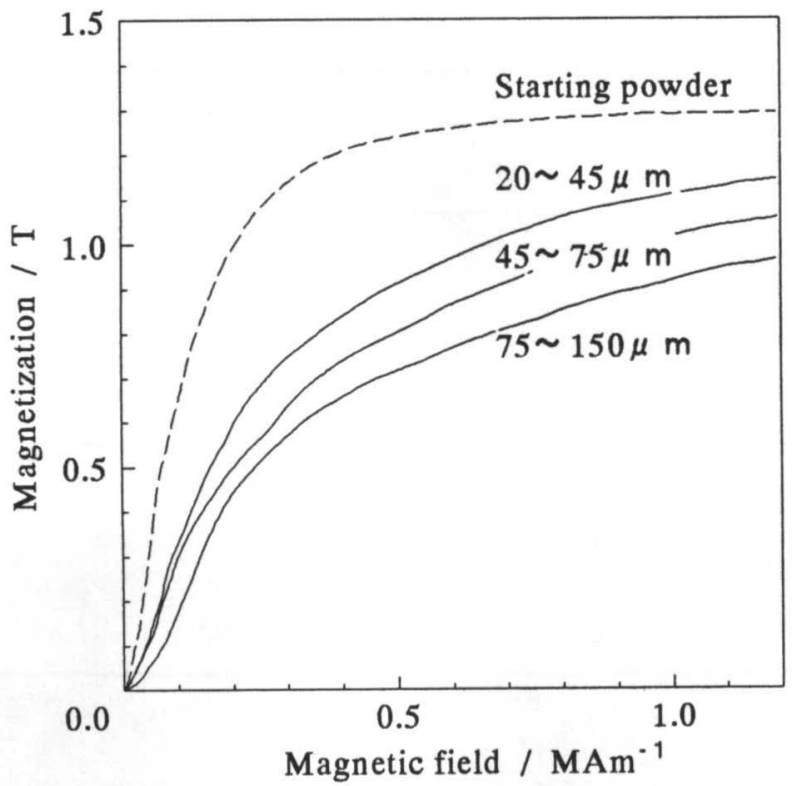

Fig.7 Initial magnetization curves of Nd-Fe-B spray dried powders separated by sieving, which include $0.4 \mathrm{wt} \%$ of PVA as a binder (solid lines). A curve of starting powder (broken line) is also indicated for comparison.

\section{2 焼結磁石の特性}

磁界中スプレー造粒で得られた異方性造粒粉, 磁界なしで 造粒した等方性造粒粉, および造粒前の原料粉末の 3 種類の 粉末と, それらを用いて成形, 脱バインダー, 焼結して得ら れた焼結体の酸素量, 炭素量の分析值を Table 2 にまとめて示 す. 造粒粉にはバインダーに起因する $0.2 \mathrm{wt} \%$ も炭素が含ま れているが, 水素中での脱バインダーによって焼結体の残留 炭素量は $0.1 \mathrm{wt} \%$ 以下に抑制され，原料粉末を出発原料とした 焼結体と同等レベルになっている。一方, 酸素量はスプレー 造粒の工程中の酸化とバインダーからの残留酸素の影響で, 造粒粉を用いた焼結体では原料粉末を用いた焼結体に比べて $0.1 \mathrm{wt} \%$ ほど高くなっている.

Fig. 8 に成形磁界 $0.88 \mathrm{MA} / \mathrm{m}$ で成形した焼結体のカー効果顕. 微鏡による組織写真を示す. 成形時の配向磁界は写真の上下 方向に印加している．大きくコントラストの異なる領域が 個々の結晶粒を示し, 粒内の縞模様は消磁状態での磁区構造 を示している. また, 磁壁面は結晶粒のc軸方向と平行になっ ている，造粒粉を出発原料とした焼結体では，通常の焼結体 に比べて明らかに結晶粒径が小さくなっていることがわかる. これは，焼結体中に含まれる酸素が主に結晶粒界に偏在し，
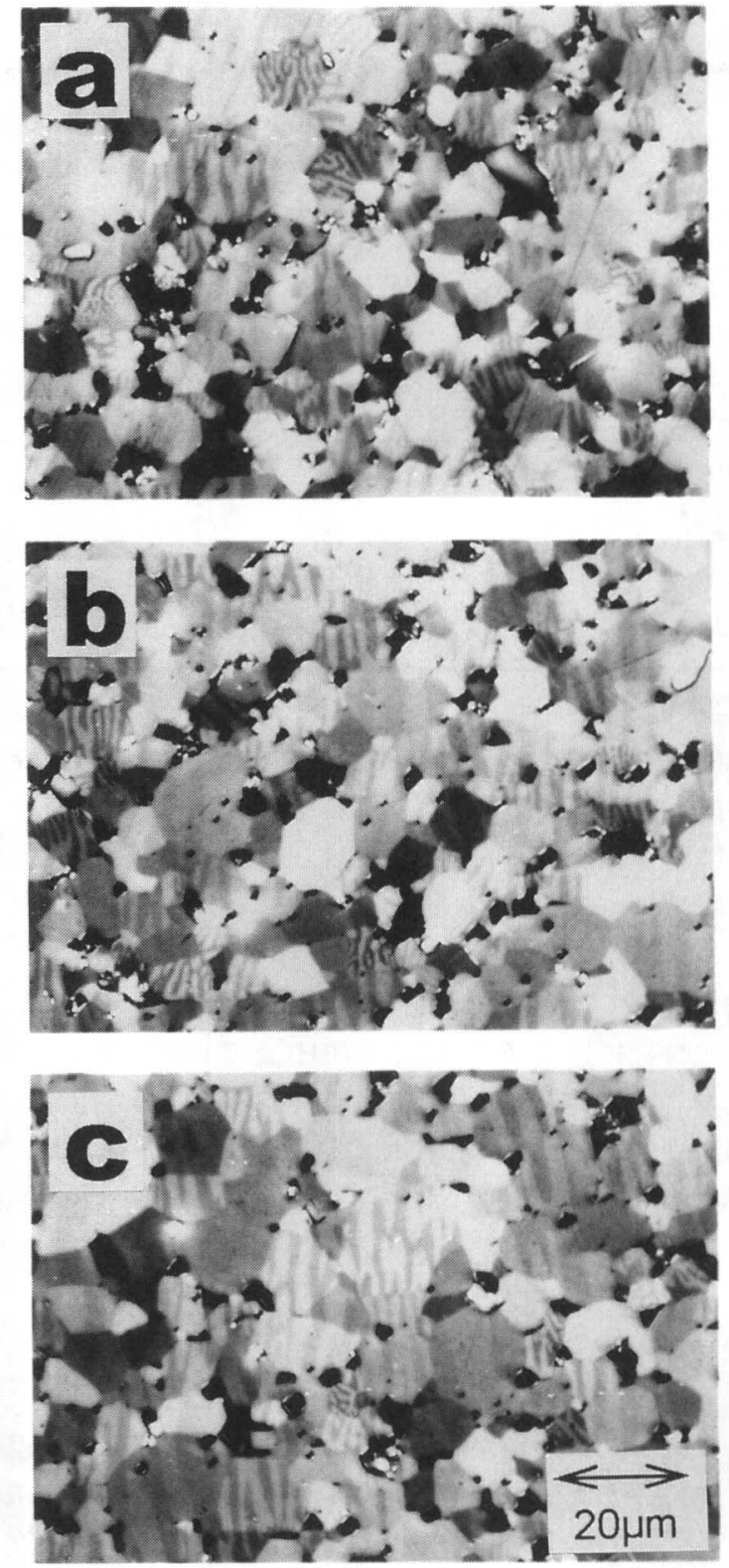

Fig.8 Kerr micrographs of sintered magnets made from (a); anisotripic spray dried powder, (b); isotropic spray dried powder and (c); starting powder. Magnetic field was applied to the vertical direction of photos.

これが焼結中の結晶粒の成長を妨げたものと推定される。 ま た, この写真では, スプレー造粒粉による焼結体 $(\mathrm{a}, \mathrm{b})$ 中に 配向の乱れた粒子が多く認められる.

Table 2 Composition of oxygen and carbon included in three kinds of powder and sintered magnets which were made from them.

\begin{tabular}{ccccccccc}
\hline & \multicolumn{2}{c}{ Anisotropic spray drying } & & \multicolumn{2}{c}{ Isotropic spray drying } & & \multicolumn{2}{c}{ Starting powder } \\
& Powder & Magnet & & Powder & Magnet & & Powder & Magnet \\
\hline Oxygen (wt\%) & 0.71 & 0.73 & & 0.75 & 0.76 & & 0.55 & 0.63 \\
Carbon (wt\%) & 0.20 & 0.09 & & 0.20 & 0.09 & & 0.06 & 0.09 \\
\hline
\end{tabular}


Table 3 Densities and magnetic properties of sintered magnets.

\begin{tabular}{|c|c|c|c|c|}
\hline $\begin{array}{l}\text { Applied field } \\
\text { at compacting }\end{array}$ & Properties & $\begin{array}{l}\text { Anisotropic spray } \\
\text { dried powder }\end{array}$ & $\begin{array}{l}\text { Isotropic spray } \\
\text { dried powder }\end{array}$ & Starting powder \\
\hline \multirow{4}{*}{$0.23 \mathrm{MA} / \mathrm{m}$} & Density $\left(\mathrm{Mg} / \mathrm{m}^{3}\right)$ & 7.38 & 7.37 & 7.51 \\
\hline & $\mathrm{B}_{\mathrm{r}} \quad(\mathrm{T})$ & 0.84 & 0.78 & 1.15 \\
\hline & $(\mathrm{BH})_{\max }\left(\mathrm{kJ} / \mathrm{m}^{3}\right)$ & 124 & 104 & 243 \\
\hline & $\mathrm{H}_{\mathrm{cJ}} \quad(\mathrm{MA} / \mathrm{m})$ & 1.04 & 1.15 & 1.04 \\
\hline \multirow{4}{*}{$0.88 \mathrm{MA} / \mathrm{m}$} & Density $\left(\mathrm{Mg} / \mathrm{m}^{3}\right)$ & 7.38 & 7.36 & 7.49 \\
\hline & $\mathrm{B}_{\mathrm{r}} \quad(\mathrm{T})$ & 1.19 & 1.17 & 1.27 \\
\hline & $(\mathrm{BH})_{\max }\left(\mathrm{kJ} / \mathrm{m}^{3}\right)$ & 265 & 257 & 307 \\
\hline & $\mathrm{H}_{\mathrm{cJ}} \quad(\mathrm{MA} / \mathrm{m})$ & 0.99 & 0.93 & 0.95 \\
\hline
\end{tabular}

Table 3 に, 成形磁界強度が $0.23,0.88 \mathrm{MA} / \mathrm{m}$ のをの焼結体 の密度と磁気特性を示す。造粒粉を用いた焼結体の密度は通 常の焼結体に比べて低い.これは，残留酸素量が多く焼結に よる緻密化が起こりにくかったためと考えられる。またた，造 粒粉を用いた場合の成形磁界 $0.23 \mathrm{MA} / \mathrm{m}$ での磁気特性は原料 粉末に比べて $\mathrm{B}_{\mathrm{r}},(\mathrm{BH})_{\max }$ が低いが, 異方性造粒粉を用いると等 方性造粒粉に比べて $\mathrm{B}_{\mathrm{r}}$ で 7.7\%, $(\mathrm{BH})_{\max }$ で $19.2 \%$ の向上がはか れた.これは，Fig.3で見たように異方性造粒粉の磁界配向性 が等方性造粒粉に比べて優れているため，成形体，および焼 結体の配向度が向上した結果と考えられる. 成形磁界が $0.88 \mathrm{MA} / \mathrm{m}$ の場合も同様に, 造粒粉の異方化によって $(\mathrm{BH})_{\max }$ で $3.1 \% の$ 向上が見られた。

焼結体の保磁力については，造粒粉を用いた場合と原料粉 末を直接成形した場合でFig.8で見たように結晶粒径に大きな 違いがあったにもかかわらず，両者の保磁力にあまり差はな かった。これ、, Nd-Fe-B焼結磁石が核生成型の保磁力機構を 持ち, 保磁力の大きさが結晶粒径のサイズに大きく依存しな いためと考えられる。

以上の検討から, 異方性造粒粉を磁界中で成形後, 焼結し て得られた磁石の $\mathrm{B}_{\mathrm{r}},(\mathrm{BH})_{\max }$ は, 同じ成形磁界で成形した等方 性造粒粉による磁石に比べて向上することがわかった。

\section{4 ま と め}

永久磁石を用いた磁気回路で発生させた磁界中で造粒した Nd-Fe-B スプレー造粒粉と，通常のスプレー造粒粉の性状を 比較して以下の結論を得た。

1. 磁界中スプレー造粒粉は, 個々の二次粒子を構成する一 次粒子の向きがそろった異方性造粒粉になっている.

2. 異方性造粒粉は等方性造粒粉と比べて磁界配向が容易で ある。

3. 異方性造粒粉を磁界中で成形後, 焼結して得られた磁石 のB,$(\mathrm{BH})_{\max }$ は, 同じ成形磁界で成形した等方性造粒粉に よる磁石に比べて向上する.

本研究に述べたスプレー造粒粉の異方化の技術は，スプ レー造粒粉を用いた Nd-Fe-B 磁石の磁気特性の向上をはかる 上で有力な手段になるものと考えられる。

\section{文献}

1) M.Sagawa, S.Fujimura, N.Togawa, H.Yamamoto and Y.Matsuura: J.Appl.Phys., 55(1984)2083.

2) 山下治, 岸本芳久: 粉体および粉末治金, 43(1996)249.

3) 山下治,岸本芳久: 粉体および粉末治金, 43(1996)675.

4) 岸本芳久,山下治: 粉体および粉末治金, 44(1997)775. 